\title{
Publisher Correction: DNA double-strand breaks in telophase lead to coalescence between segregated sister chromatid loci
}

\author{
Jessel Ayra-Plasencia (10 1,2 \& Félix Machín (10 1,3
}

Correction to: Nature Communications https://doi.org/10.1038/s41467-019-10742-8, published online 28 June 2019.

The original version of this Article contained an error in Fig. 6e, in which the labels 'IAA' and 'Phle' in the bottom right where inadvertently omitted. This has been corrected in both the PDF and HTML versions of the Article.

Published online: 02 August 2019

\begin{abstract}
(c) (i) Open Access This article is licensed under a Creative Commons Attribution 4.0 International License, which permits use, sharing, adaptation, distribution and (C) reproduction in any medium or format, as long as you give appropriate credit to the original author(s) and the source, provide a link to the Creative Commons license, and indicate if changes were made. The images or other third party material in this article are included in the article's Creative Commons license, unless indicated otherwise in a credit line to the material. If material is not included in the article's Creative Commons license and your intended use is not permitted by statutory regulation or exceeds the permitted use, you will need to obtain permission directly from the copyright holder. To view a copy of this license, visit http://creativecommons.org/licenses/by/4.0/.
\end{abstract}

(c) The Author(s) 2019

\footnotetext{
${ }^{1}$ Unidad de Investigación, Hospital Universitario Nuestra Señora de Candelaria, Santa Cruz de Tenerife, Spain. ${ }^{2}$ Escuela de Doctorado y Estudios de Posgrado, Universidad de La Laguna, Santa Cruz de Tenerife, Spain. ${ }^{3}$ Instituto de Tecnologías Biomédicas, Universidad de La Laguna, Santa Cruz de Tenerife, Spain. Correspondence and requests for materials should be addressed to F.M. (email: fmachin@funcanis.es)
} 